\title{
KERAGAMAN HIJAUAN PAKAN DI KUNAK (KAWASAN USAHA PETERNAKAN) SAPI PERAH BOGOR
}

\author{
Permana, A.T., M.A. Setiana, dan I.I. Arbi \\ Departemen Ilmu Nutrisi dan Teknologi Pakan, Fakultas Peternakan, Institut Pertanian Bogor \\ Email: aseptp@yahoo.com
}

\begin{abstract}
ABSTRAK
Hijauan pakan mempunyai peranan penting dalam keberhasilan usaha sistem peternakan sapi perah. Peternak di KUNAK Bogor memenuhi kebutuhan hijauan pakannya dari hijauan pakan yang dibudidayakan maupun dari hijauan pakan liar yang diambil dari sekitarnya. Sehubungan dengan kualitas hijauan pakan salah satunya ditentukan oleh jenis tanamannya, pemilihan jenis hijauan pakan sangatlah penting. Penelitian ini bertujuan untuk melihat keragaman hijauan pakan yang ada di KUNAK dan beberapa kualitas hijauan pakan berupa protein kasar (PK )dan serat kasar (SK). Penelitian dilakukan melalui survey lapangan dan pengambilan sampel hijauan pakan untuk dilakukan identifikasi dan dianalisa PK dan SK- nya. Komposisi botani tiga terbanyak di KUNAK 1 adalah rumput Ottochloa nodosa, Brachiariaruziziensis, dan Pennisetum purpureum, sedangkan komposisi botani di KUNAK 2 adalah Pennisetum purpeureum Schum, Ottochloa nodosa dan Euleusine indica. Sedangkan hasil analisa PK dan SK pada Ottochloa nodosa (PK : 9,1\%; SK : 28 \%), Brachiaria ruziziensis (PK: 7,4\%; SK: 25,4\%), dan Pennisetum purpureum (PK: 8,6\%; SK: 30,7\%)
\end{abstract}

Kata kunci: tanaman hijaun pakan, KUNAK, komposisi botani, Pennisetum purpeureum, Ottochloa nodosa

\section{PENDAHULUAN}

Ketersediaan hijauan pakan bagi suatu kawasan peternakan adalah sangat penting dalam menunjang keberhasilan usaha peternakan di kawasan tersebut. Kebutuhan ternak akan pakan hijauan menurut Soetanto (1994) adalah sekitar $36 \mathrm{~kg}$ perhari pada sapi laktasi. Hasil penelitian Dziyauddin (2012) menemukan bahwa kawasan usaha peternakan ini kekurangan pakan hijauan sehingga membuat para peternak harus mencari keluar kawasan. Masih menurut Dziyauddin (2012) untuk mencukupi kebutuhan ternak yang ada saat ini dibutuhkan perluasan lahan penanaman hijauan pakan sekitar 101,5 hektar.

Selain ketersediaan pakan hijauan, kualitas tanaman jugamerupakan hal yang penting dalam menunjang keberhasilan usaha peternakan. Kualitas tanaman salah satunya tergantung daripada jenis tanaman. Jenis tanaman dari family legume mempunyai kandungan protein yang lebih tinggi dari family rumput-rumputan. Ketersediaan hijauan pakan yang cukup dengan kualitas hijauan pakan yang baik dapat menunjang keberhasilan usaha ternak di kawasan tersebut.

Kawasan usaha peternakan sapi perah (kunak), merupakan kawasan peternakan yang berlokasi di Kecamatan Cibungbulang dan Kecamatan Pamijahan, Kabupaten Bogor. Kawasan ini menempati luasan areal sekitar 94,41 hektar (KPS-UPB 2012). Tujuan dari kegiatan survey ini adalah untuk melihat keragaman jenis yang ada di lokasi kawasan usaha peternakan.

\section{METODE PENELITIAN}

\section{Tempatdan Waktu Penelitian}

Penelitian ini dilakukan di Kawasan Usaha Peternakan (KUNAK) Sapi Perah Bogor, di Kecamatan Cibungbulang (KUNAK1) dan Kecamatan Pamijahan (KUNAK 2), Kabupaten Bogor, dari September hingga Desember 2013.

\section{Analisis Komposisi Botani}

Analisis komposisi botani yang dilakukan menggunakan metode "Dry Weight Rank" menurut Mannetje dan Haydock (1963). Bingkai kuadran 0.5 mxo.5 m disebar secara acak sebanyak 75 kali baik pada KUNAK 1 maupun KUNAK 2, jenis tanaman yang ada di dalam kuadran tersebut dicatat dan dihitung menggunakan tetapan koefisien padaTabel1.

Tabel 1. Tetapan Koefisien Komposisi Botani (Mannetje dan Haydock, 1963)

\begin{tabular}{cc}
\hline Rangking & Tetapan Koefisien \\
\hline 1 & 8.04 \\
2 & 2.41 \\
3 & 1 \\
\hline
\end{tabular}

\section{Analisis Vegetasi}

Pada petak pengamatan yang berukuran $20 \mathrm{~m}$ x $20 \mathrm{~m}$, ditentukan 5 plot anak petak berukuran 
$2 \mathrm{~m} \times 2 \mathrm{~m}$. Pada masing - masing anak plot tadi frekuensi masing - masing tanaman dihitung. Rumus perhitungan untuk INP (Indeks Nilai Penting), $\mathrm{H}^{\text {c }}$ (Indeks Keragaman Jenis), $\mathrm{R}_{1}$ (Indeks Kekayaan Jenis), E (Indeks Kemerataan Jenis), ID (Indeks Dominasi), dan IS (Indeks Kesamaan Komunitas) disajikan padaTabel 2.

Tabel 2. Perhitungan Analisis Vegetasi (Soerianegara dan Indrawan, 2008)

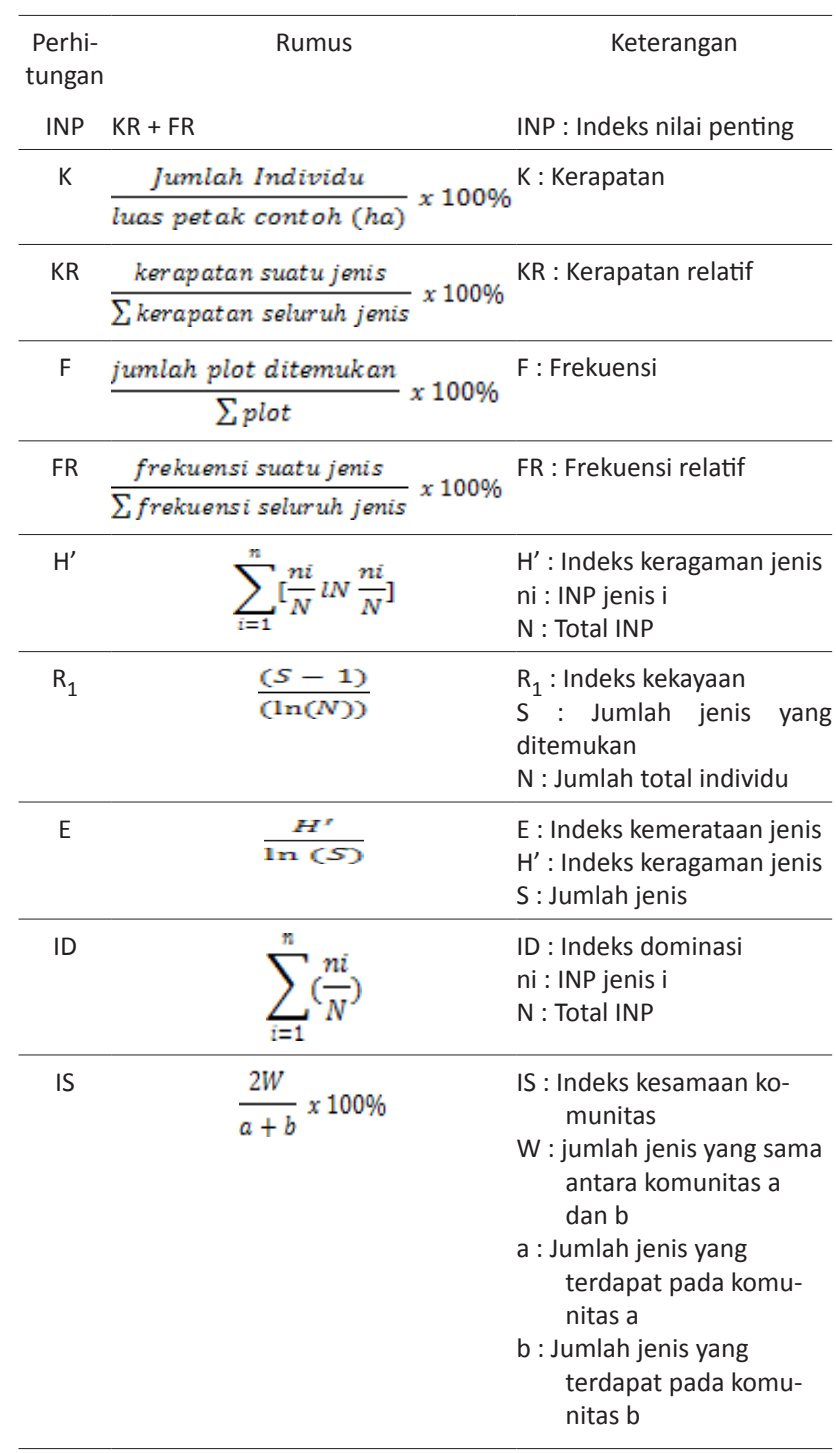

\section{Kualitas Hijauan Pakan}

Sampel hijauan pakan dari dianalisa untuk kandungan Protein Kasar (PK) dan Serat

Kasar (SK) untuk tanaman yang dominan dalam komposisi botaninya.

\section{HASIL DAN PEMBAHASAN}

\section{Komposisi Botani}

Penentuan komposisi botani pada KUNAK 1 dan 2 disajikan dalamTabel 3 dan Tabel 4 .
Tabel 3.Komposisi Botani KUNAK 1

\begin{tabular}{cllll}
\hline No Jenis & Nama latin & Nama lokal & \% Jenis \\
\hline 1 & Rumput & Ottochloa nodosa (Kunth) & Sarang buaya & 11.83 \\
2 & Rumput & Brachiaria ruziziensis Mez. & - & 10.34 \\
3 & Rumput & Pennisetum purpureum Schum. & Rumput gajah & 8.88 \\
4 & Rumput & Pannicum maximum var. Gatton & - & 8.53 \\
5 & Rumput & Axonopus affinis Chase. & - & 7.19 \\
6 & Rumput & Cenchrus ciliaris L. & - & 7.01 \\
7 & Rumput & Brachiaria mutica (Forsk.) Stapf & - & 6.19 \\
8 & Rumbah & Wedelina Montana varpilosa H. & Jotang liar & 5.05 \\
9 & Rumput & Eleusine indica (L.) Gaertn & Ki pait & 5.03 \\
10 & Rumbah & Eupatorium odoratum L.f. & Jotang munding & 2.95 \\
\hline
\end{tabular}

Tabel 4. Komposisi Botani KUNAK 2

\begin{tabular}{rllll}
\hline No & Jenis & Nama latin & Nama lokal & \% Jenis \\
\hline 1 & Rumput & Pennisetum purpureum Schum. & Rumput gajah & 14.24 \\
2 & Rumput & Ottochloa nodosa (Kunth) & - & 13.37 \\
3 & Rumput & Eleusine indica L.Gaertn & Ki pait & 7.40 \\
4 & Rumbah & Mimosa pudica L. & Putri malu & 6.92 \\
5 & Rumput & Brachiaria mutica (Forsk.)Stapf & Lamata & 5.60 \\
6 & Rumput & Axonopus affinis Chase. & - & 4.54 \\
7 & Rumput & Panicum repens L. & Jajahean & 4.54 \\
8 & Rumput & Axonopus compressus & Lelempeng & 3.49 \\
9 & Rumput & Imperata cylindrical Beauv. & Alang-alang & 3.49 \\
10 & Rumput & Brachiaria decumbens & - & 3.20 \\
\hline
\end{tabular}

Komposisi botani Kunak 1 didominasi oleh Ottochloa nodosa (Kunth) (11.83\%) sedangkan Kunak 2 didominasi oleh Pennisetum purpureum (14.24\%). Ottochloa nodosa merupakan rumput menyebar terutama di kawasan Asia Tenggara dengan penyebaran di sekitar perkebunan atau ladang, panjang rumput ini berkisar antara $30-120 \mathrm{~cm}$ (FAO, 2016). Perbedaan ini terjadi kemungkinan karenapada Kunak 1 lahan sedikit berbukit serta banyak lahan pemukinan yang penghuninya yang tidak berprofesi sebagai peternak lebih sedikit dibandingkan dengan Kunak 2. Sedangkan pada Kunak 2 lahannya memang dengan sengaja ditanami oleh tanaman Pennisetum purpureum.

\section{Indeks Nilai Penting}

Indeks Nilai Penting merupakan salah satu cara dalam menganalisa vegetasi dalam suatu wilayah. Indeks Nilai Penting merupakan penetapan dominasi suatu jenis terhadap yang lainnya. INP ini juga merupakan penjumlahan antara Kerapatan Relatif (KR) dengan Frekuensi Relatif (FR) (Soerianagara dan Indrawan, 1998).

\section{Keragaman Hijauan Pakan}

Indeks Keragaman Jenis menurut Magurran (1988) dibedakan menjadi: rendah (<2.0), sedang $(2.0-3.0)$, dan tinggi (>3.0). Berdasarkan klasifikasi tersebut Indeks Keragaman Jenis dari kedua KUNAK tersebut termasuk ke dalam sedang (Tabel7). Indeks Kekayaan 
Tabel 5. Indeks Nilai Penting (INP) Hijauan Pakan Kunak1

\begin{tabular}{|c|c|c|c|c|c|c|}
\hline \multirow{2}{*}{\multicolumn{2}{|c|}{ No Nama latin }} & \multicolumn{4}{|c|}{ Jumlah } & \multirow[b]{2}{*}{ INP (\% } \\
\hline & & Nama Lokal & $\begin{array}{l}\text { indi- } \\
\text { vidu }\end{array}$ & $\mathrm{KR}(\%)$ & $\mathrm{R}(\%$ & \\
\hline 1 & $\begin{array}{l}\text { Ottochloa nodosa } \\
\text { (Kunth) }\end{array}$ & - & 100 & 21.01 & 12 & 33.01 \\
\hline 2 & Eupatorium odoratum & Jotang munding & 54 & 11.34 & 12 & 23.34 \\
\hline 3 & Cenchrus ciliaris L. & - & 52 & 10.92 & 12 & 22.92 \\
\hline 4 & $\begin{array}{l}\text { Pennisetum purpu- } \\
\text { reum Schum }\end{array}$ & Rumput gajah & 61 & 12.82 & 4 & 16.82 \\
\hline 5 & Brachiaria mutica & Lamata & 39 & 8.19 & 8 & 16.19 \\
\hline 6 & $\begin{array}{l}\text { Brachiaria ruziziensis } \\
\text { Mez. }\end{array}$ & - & 21 & 4.41 & 8 & 12.41 \\
\hline 7 & $\begin{array}{l}\text { Eleusineindica (L.) } \\
\text { Gaertn }\end{array}$ & Ki pait & 40 & 8.40 & 4 & 12.40 \\
\hline 8 & Brachiaria decumbens & - & 17 & 3.57 & 8 & 11.57 \\
\hline 9 & Mimosa pudica L. & Putri malu & 11 & 2.31 & 8 & 10.31 \\
\hline & $\begin{array}{l}\text { Amaranthus gracilis } \\
\text { Desf. }\end{array}$ & - & 29 & 6.09 & 4 & 10.09 \\
\hline
\end{tabular}

Tabel 6. Indeks Nilai Penting (INP) Hijauan Pakan Kunak 2

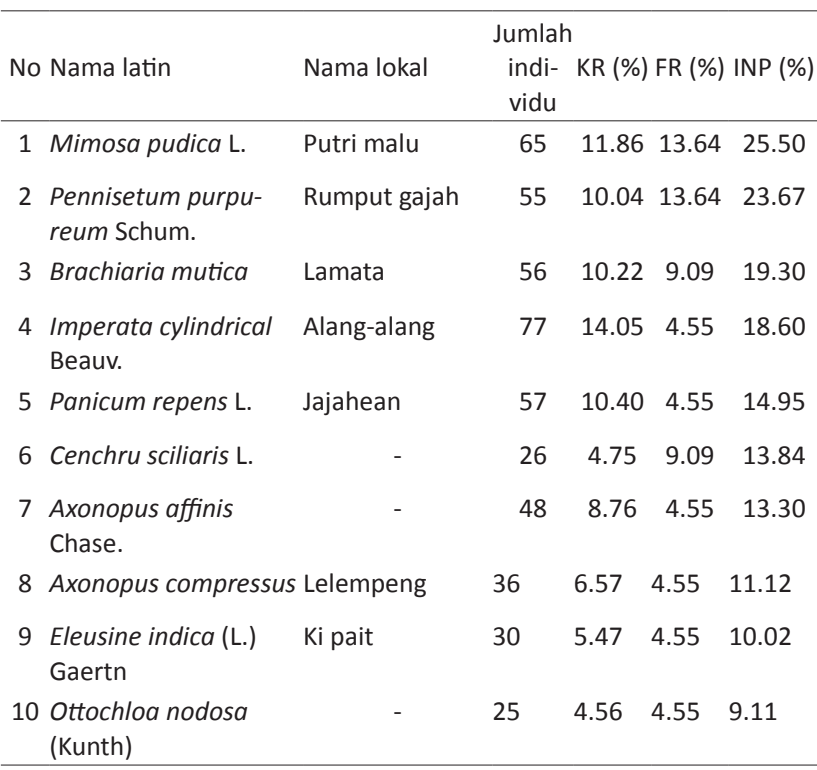

Jenis menurut Indriyanto (2015) dibedakan menjadi rendah apabila $R_{1}<1$ dan tinggi $R_{1}>1$. Nilai Indeks Kekayaan Jenis pada kedua KUNAK tersebut termasuk ke dalam tinggi. Indeks Kemerataan Jenis menurut Magguran (1988) dibedakan menjadi rendah $(\mathrm{E}<3)$, sedang (3-6) dan tinggi $(\mathrm{E}>6)$. Menurut klasifikasi tersebut di daerah KUNAK tersebut termasuk ke dalam skala rendah, artinya tidak merata. Indeks Dominasi Jenis di daerah KUNAK bernilai o.o8o.09, dimana menurut Krebs (1978) angka Indeks Dominasi yang mendekati nol menunjukan adanya dominasi beberapa jenis tertentu di dalam suatu ekosistem. Indeks Kesamaan Komunitas merupakan Indeks yang menunjukan kesamaan vegetasi dari dua wilayah. Indeks Kesamaan $<75 \%$ terjadi perbedaan vegetasi yang cukup tinggi pada dua wilayah (Istomo dan Kusmana, 1997). Pada KUNAK 1 dan KUNAK 2 mempunyai nilai Indeks Kesamaan 83.87\%, ini menunjukan terdapat kesamaan tumbuhan yang relative tinggi dari keduanya.

\section{Kualitas Hijauan Pakan}

Nilai Protein Kasar tertinggi (9.1) dari hijauan pakan yang ada di KUNAK ada pada Ottochloa nodosa sedangkan Pennisetum purpureum hijauan pakan yang umum dipakai peternak di Kunak mempunyai Nilai PK dan SK-nya dibawah Ottochloa nodosa. Halini disebabkan produktivitas yang tinggi dari Pennisetumpur pureum dibandingkan Ottochloa nodosa.

Tabel 7. Analisis keragaman hijauanpakan KUNAK 1 dan KUNAK 2

\begin{tabular}{cccccc}
\hline Lokasi & $\begin{array}{c}\text { Indeks } \\
\text { Keragaman } \\
\text { Jenis } \\
\mathrm{H}^{\prime}\end{array}$ & $\begin{array}{c}\text { Indeks } \\
\text { Kekayaan } \\
\text { Jenis } \\
\mathrm{R}_{1}\end{array}$ & $\begin{array}{c}\text { Indeks Ke- } \\
\text { merataan } \\
\text { Jenis } \\
\mathrm{E}\end{array}$ & $\begin{array}{c}\text { Indeks } \\
\text { Dominasi } \\
\text { ID }\end{array}$ & $\begin{array}{c}\text { Indeks } \\
\text { Kesamaan } \\
\text { Komunitas } \\
\text { IS (\%) }\end{array}$ \\
\hline Kunak 1 & 2.56 & 2.27 & 0.94 & 0.09 & 83.87 \\
Kunak 2 & 2.66 & 2.38 & 0.96 & 0.08 & \\
\hline
\end{tabular}

Tabel 8. Kualitas Nutrisi Hijauan Pakan

\begin{tabular}{lcc}
\hline \multicolumn{1}{c}{ Nama Latin } & PK (\%) & SK (\%) \\
\hline Ottochloa nodosa (Kunth) & 9.1 & 28.4 \\
Brachiaria ruziziensis Mez. & 7.4 & 25.4 \\
Pennisetum purpureum Schum. & 8.6 & 30.7 \\
Eleusine indica (L.) Gaertn & 8.1 & 26.5 \\
\hline
\end{tabular}

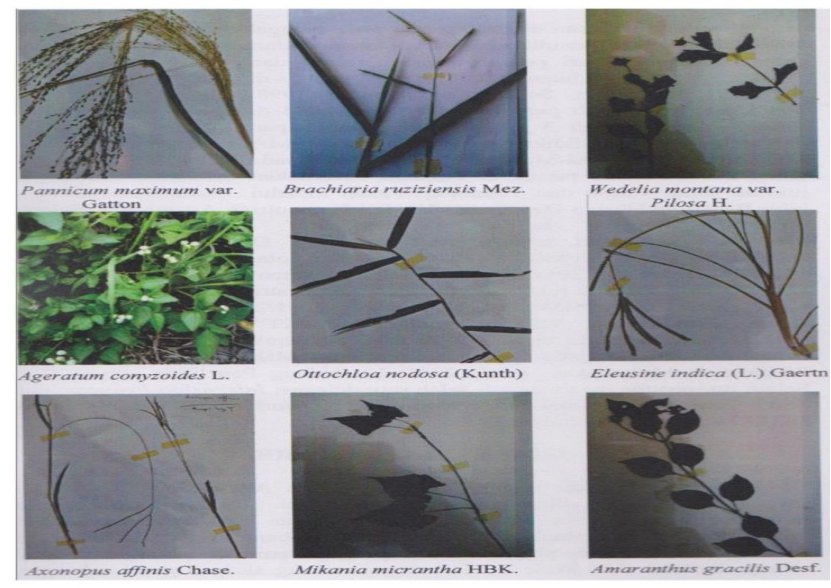

Gambar 1. Foto jenis tanaman yang ditemukan pada lokasi Kunak

\section{KESIMPULAN}

Ottochloa nodosa (Kunth), Brachiaria ruziziensis Mez. Dan Pennisetum purpureum Schum. Mendominasi pada KUNAK 1, sedangkan KUNAK 2 didominasi oleh Pennisetum purpureum Schum., Ottochloa nodosa (Kunth) dan Eleusine indica (L.) Gaertn. Kualitas hijauan pakan dominan di KUNAK mempunyai rataan PK 8.5\%dan SK 28.4\%. 


\section{REFERENSI}

Dziyauddin, M. 2012. Aplikasi Sistem Informasi Geografis Untuk Melihat Penyediaan Hijauan Pakan dan Pemanfaatan Lahan di Kawasan Usaha Peternakan Sapi Perah Kabupaten Bogor. [Skripsi]. Bogor (ID). Fakultas Peternakan, IPB. Bogor.

FAO. 2016. Ottochloa nodosa (Kunth) Dandy. www.fao.org/ag/Agp/agpc/doc/Gbase/data/ pfooo491.htm (Akses : 27Juli2016)

Indriyanto. 2005. Ekologi Hutan. Bumi Aksara. Jakarta.

Istomo, Kusmana, C. 1997. Penuntun Praktikum Ekologi Hutan. Bogor (ID): Institut Pertanian Bogor. Bogor.

Krebs, C.J. 1978. Ecology The Experimental Analysis of Distribution and Abudance. New York (US). Harper and Row Publisher.

[KPS-UPB] Koperasi Produksi Susu dan Usaha
Peternakan Bogor. 2012. Laporan Pertanggung jawaban Pengurus KPS-Bogor Tahun Buku 2012. KPS Bogor. Bogor.

Magurran, A.E. 1988. Ecological Diversity and Its Measurenment. Princeton NJ (US): Princeton University Press.

Mannetje, L. \& Haydock, K.P. 1963. The Dry Weight Rank Method for The Botanical Analysis of Pasture. J.British Grassland Society. 18(4):268275.

Soerianegara, I. Dan Indrawan A. 2008. Ekologi Hutan Indonesia. Bogor (ID): Institut Pertanian Bogor. Bogor.

Soetanto, H. 1994. Upaya efisiensi penggunaan konsentrat dalam ransum sapi perah laktasi. Prosiding Pertemuan Ilmiah Pengolahan dan Komunikasi Hasil Penelitian Sapi Perah. Pasuruan, 26 Maret 1994. Sub Balai Penelitian Ternak Grati. Pasuruan. 